\title{
Social history of Capoeira through images. The Raul Pederneiras' "silhouettes"
}

\author{
Paulo Coêlho ARAÚJO*, \& Ana Rosa JAQUEIRA \\ Faculdade de Ciências do Desporto e Educação Física - Universidade de Coimbra (Portugal) \\ Laboratório de Jogos, Recreação, Lutas Tradicionais e Capoeira - LUDUS/FCDEFUC (Portugal) \\ International Martial Arts and Combat Sports Scientific Society - IMACSSS (Poland)
}

\section{Introduction}

The interest in this approach to image interpretation attributed directly or even indirectly to Capoeira fight/game comes from several distinct factors, from which we emphasize the almost inexistence of imagetic analysis of Capoeira, as well as our identification in its specific literature, superficial and scarcely informed interpretations of some of the iconography that portrayed the presence of this cultural expression in the Brazilian society in the nineteenth and twentieth centuries.

\section{Methodology}

The present study is based on three main scientific principles. The inherent principles of Historical Archaeology, a search field structured by professional American archaeologists in the 60s, the scientific arguments presented by Panofsky (1986) on the interpretation of imagery and historical and ethnographical methods, which will allow us to analyse documents stored in Brazilian libraries and archives, and also bibliography about Capoeira during the twentieth centuries.

As to the sources looked at, among those presented to us in the context of Historical Archaeology, we highlight the ones translated in pictorial information and expressed in drawings, paintings, cartoons and photographs. For this study, we selected an iconography with the artistic motive identified as "Silhouette" by its author, Raul Pederneiras (Revista da Semana, 1926).

\section{Analysis and discussion of results}

From this artist's work and the speech that followed its publication, it's highlighted the apology of Brazilian's fight (Revista da Semana, 1921), and even considered its supremacy over other selfdefense expressions known at the time in Brazil, besides recognizing the potential of Capoeira as a physical exercise

Besides referring the potentialities of Capoeira, the author comments some facts that permeated the context of this Brazilian fight, highlighting the interference of its practitioners in the context of Brazilian politics, influencing the election results, and presenting themselves as bodyguards recruited by politicians, and even referring its most famous practitioners and the different social classes they belonged to in Brazilian society. He also identifies the gangs of Capoeira formed by different groups of individuals, including Capoeira practitioners of this period, alluding to their characteristic language and typical costumes in the context of Carioca society of the late nineteenth and early twentieth century. 


\section{Conclusion}

The iconography presented by Pederneiras in 1926, allowed us to reconstruct the history of this corporal expression movements in different spaces and times, given the lack of visual records that effectively represent how it was carried out, the strokes and movements, some of these similar to those presented by different authors at different times and that constituted the gestures framework of this Brazilian fight.

This timeline outlined through the diverse iconography presented by those various artists, when accompanied by a set of different documents and works written during the nineteenth and twentieth centuries, show a significant content that allows the deconstruction and demystification of some ideological speeches that aim to defend the appearance and creation of Capoeira firstly on the African continent in an specific ethnic group, thus denying the recognition of different cultural contributions from other ethnic groups and body languages present in the formation of Brazil and in this cultural manifestation.

In an iconographic as well as descriptive way, Pederneiras and many other artists that portrayed Capoeira in the nineteenth and early twentieth century, sought with these communication forms, to raise awareness among government authorities to adopt the Brazilian fightas a national identity element of Brazilians and recognize it as the expression of National Gymnastics.

\section{References}

Panofsky, E. (1986). Estudos de Iconologia. Temas humanísticos na Arte do Renascimento. Lisboa: Imprensa Universitária, Editorial Estampa.

Pederneiras, R. (1926). 0 Nosso Jogo. Revista da Semana.

Pederneiras, R. (1921). A Defesa Nacional. Revista da Semana.

Key words: Capoeira; martial arts; combat sports; History of sport. 